\title{
EDAPHIC GROWTH CONDITIONS CENTAURIUM ERYTHRAEA RAFH. IN CONDITIONS OF TRANSCARPATHIA
}

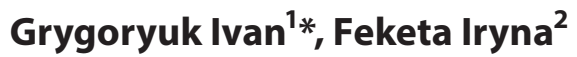 \\ ${ }^{1}$ The National University of Life and Environmental Sciences of Ukraine, Kiev, Ukraine \\ ${ }^{2}$ Uzhhorod National University, Uzgorod, Ukraine
}

\section{ЕДАФІЧНІ ОСОБЛИВОСТІ ЗРОСТАННЯ CENTAURIUM ERYTHRAEA RAFH. В УМОВАХ ЗАКАРПАТТЯ}

\section{Григорюк Іван, Фекета Ірина}

The results of researches of the edaphic growth conditions Centaurium erythraea Rafh. in conditions of the Transcarpathia are represented in this article. Centaurium erythraea often grows in the Carpathians at meadows, forest glades, mountain slopes. The plant is found in small groups in the phytocenosis. We conducted soil conditions studies at 5 locations in different natural zones of Transcarpathia. During The plant's distribution, the ecological and soil conditions of the growth of Centaurium erythraea were determined. The soil analysis was carried out at the points where plant groups with a predominance of Centaurium erythraea of an average in natural populations over an area of $5 \mathrm{~m}^{2}$. Plants of Centaurium erythraea are unpretentious to the soil and climatic conditions, grow in different soils. Particularly widespread acquires Centaurium erythraea on sod-podzolic soils, as the main component of the mixtures with grasses. But this thesis is not confirmed yet in terms of the Carpathian region. Given this current is to clarify areas of distribution of a Centaurium erythraea in the wild state and its culture in crops, in order to establish demands to the soil conditions and the definition of the yield level, various mechanical composition and physical and chemical properties of soils.

Keywords: Centaurium erythraea; natural populations; soil conditions; area; yield

\section{Вступ}

Одним із основних джерел одержання лікарських і профілактичних засобів сучасної медицини $\epsilon$ лікарські рослини, яких у Закарпатській області $\epsilon$ велика кількість. Суттєво зростає попит на рослини золототисячника малого (Centaurium erythraea Raf. (Centaurium unbellatum Gilib., C. minus Moenus p.), який перспективний для інтродукції (Деркач і Деркач, 2006; Григорюк та ін., 2008), запаси якого зменшились більш ніж у 10 разів і знаходяться на межі виснаження (Манівчук, 2003).

За цих умов $\epsilon$ важливим дослідження едафічних особливостей зростання природних популяцій Centaurium erythraea. Найоптимальнішими для вирощування Centaurium erythraea вважаються середні і важкі ґрунти, а на насіння - середні, легкі з середньою вологістю та забезпеченістю поживними речовинами.

*Corresponding author: Ivan Grygoryuk, The National University of Life and Environmental Sciences of Ukraine, Kiev, Ukraine, $\triangle$ annetnikonorova@gmail.com 


\section{Матеріали та методи}

Centaurium erythraea - одно- або двохрічна трав'яниста рослина, яка надзвичайно чутлива до антропогенного навантаження, відноситься до родини Тирличевих (Gentianaceae), містить алкалоїди, гіркі глікозиди, флавоноїди, ксантони (Товстуха, 1990).

Рослини застосовуються у медицині для приготування настоїв, відварів і гіркої настойки для поліпшення функціонування діяльності органів травлення, як зміцнюючий засіб. Centaurium erythraea виявляє антимутагенну та радіопротекторну дію, слугує компонентом лікувальних зборів при цукровому діабеті, гіпертензії, гінекологічних захворюваннях, алкоголізмі, причому побічної дії препаратів на організм не виявлено (Товстуха, 1990).

Показано, що Centaurium erythraea - переважно середньоазіатсько-європейський вид, який зростає на території Західної Європи і України, але найчастіше в Карпатах на луках, лісових галявинах, гірських схилах та біля боліт. Характерним для нього $\epsilon$ розсіяний розподіл у рослинному покриві невеликими куртинами (Фекета, 2011).

Екологічні умови місцезростання Centaurium erythraea, як дикоростучої популяції досліджували маршрутним методом. Виявлено 17 популяції Centaurium erythraea. Грунтовніші дослідження грунтових умов нами проведено в 5 точках, що розташовані в різноманітних природних зонах Закарпаття. У процесі обстеження визначали місце поширення, угрупування, екологічні та грунтові умови місцезростання Centaurium erythraea. У точках, де виявлено рослинні угрупування 3 переважанням Centaurium erythraea в природних популяціях на

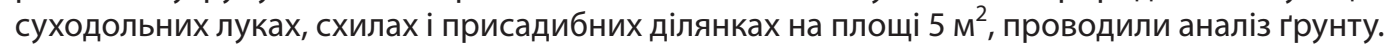

Для визначення механічного і фізико-хімічного складу ґрунту та агрохімічних показників відбирали зразки грунту з горизонту A - гумусо-акумулятивного шару. Отримані результати дали можливість визначити чутливість Centaurium erythraea до умов ґрунтового середовища, яке впливає на його здатність витримувати негативні температури навколишнього середовища. Вміст гумусу в грунті встановлювали за Тюріним, pH сольової витяжки комбінованим індикатором, гідролітичну кислотність за Каппеном, суму увібраних основ за Каппеном-Гільковіцем, рухомі форми фосфору (фотокалориметричним методом), калій за Пейве (Доспехов, 1968; Починок, 1976). Аналізи проведено в 4-х повторностях і оброблено статистично (Доспехов, 1968).

\section{Результати та їх обговорення}

Встановлено, що у низинній зоні переважаючими є дерново-підзолисті, дернові глейові і лучні глейові грунти, на яких зростає золототисячник малий. Необхідно зазначити, що дерновопідзолисті оглеєні ґрунти мають пилувату структуру гумусового шару і щільний ілювіальний шар, що обумовлює незбалансованість водно-повітряного режиму.

Вони суттєво напливають, а при підсиханні на їх поверхні утворюється щільна кірка. Кислі грунти слабо забезпечені рухомими формами калію і фосфору, тому потребують вапнування.

Дерново-підзолисті ґрунти мають товщину гумусового шару до 25 - 35 см, і зернистогрудкувату структуру, їх механічний склад середньо- й легкосуглинистий, в якому переважає грубий пил, значна кількість піску та намулу. Нижче гумусового шару розташовані елювіальний та ілювіальний злегка ущільнені шари. Це грунти слабокислі, з високою проникністю повітря і вологи, вміст гумусу - 1,3 - 2,0 \%, середньою забезпеченістю рухомими формами поживних речовин. У дощовий період на їх поверхні нагромаджуюються атмосферні опади.

Передгірна частина характеризується переважанням буроземно-підзолистих пилуватосередньосуглинистих і дерново-буроземних середньоглибоких піщано-середньосуглинистих грунтів.

Виявлено, що буроземно-підзолисті пилувато-середньосуглинисті грунти характеризуються низькими фізико-хімічними властивостями, зокрема слабим водно-повітряним режимом 
і швидким набуханням за умов зволоження. Ці фактори негативно впливають на ріст, розвиток кореневої системи та продуктивність як однорічних так і багаторічних рослин.

По всьому профілю грунти слабопроникні для води і повітря, слабо насичені увібраними основами (4,6 м-екв. на 100 г абсолютно сухого грунту) причому ступінь насичення лише 30 \%. Для них характерна кисла реакція ( $\mathrm{pH} 4,0)$, низька гідролітична кислотність - 10,85 і забезпеченість фосфором - 1,0 та калієм 3,4 мг на 100 г абсолютно сухого грунту.

Гумусний горизонт у дерново-буроземних середньоглибоких піщано-середньосуглинистих грунтах верхній досягає глибини 24 - 25 см 3 дрібно-грудкуватою структурою і високою водопроникністю. Їх грунтовий комплекс оптимально насичений основами, при цьому гідролітична кислотність досягає 3,15, сума увібраних основ становить 11,4 м-екв. на 100 г абсолютно сухого грунту, pH - 5,0. Це слабо забезпечені гумусом - 1,97 \%, середньо легкорозчинним фосфором - 5,0 та недостатньо калієм - 3,4 мг на 100 г абсолютно сухого грунту. Характерною ознакою дерново-буроземних глеєвих піщано-середньосуглинистих грунтів $\epsilon$ оглеєння грунтового профілю.

Колір грунту сірувато-бурий, грудкуватої структури. Верхній гумусний горизонт коливається від 5 до 16 см. Низькі їх фізичні властивості обумовлені постійним перезволоження з гігроскопічною вологістю 6,25 \%, ступенем насичення 70 \% та сумою увібраних основ - 13,4 м-екв. на 100 г абсолютно сухого грунту. Для них характерна слабокисла реакція грунтового розчину, низький вміст рухомих форм калію та фосфору.

Зв'ясовано, що гірські лучно-буроземні грунти поширені на полонинах і в приполонинській смузі в субальпійському та альпійському висотних поясах від 1100 до 1400 м над рівнем моря. За будовою профілю вони нагадують неглибокі або середньоглибокі бурі лісові. У гірській зоні (полонина Руна, 1482 м над рівнем моря) основними $\epsilon$ бурі гірсько-лісові середньо-глибокі пилувато-легкосуглинкові (грунтовий профіль до 80 см) й бурі лісові неглибокі кам'янисті пилувато-середньосуглинисті (до 60 см) ґрунти. Перші зустрічаються на менш крутих схилах з гумусовим шаром 18 - 25 см і вмістом гумусу - 2,5 - 3,5 \%, а вище над рівнем моря - до 4,5\%.

Бурі гірсько-лісові неглибокі грунти за фізико-хімічними властивостями поступаються середньоглибоким. Нами встановлено, що їх механічний склад пилувато-середньосуглинистий із перевагою глинистих фракцій. Грунти характеризується низькими фізико-хімічними властивостями, які середньо насичені увібраними основами з ступенем їх насичення - 72 \%, кислою реакцію грунтового розчину (рН сольове - 5,2) та гідролітичною кислотністю 3,67 м-екв. на 100 г абсолютно сухого грунту. Водночас дані грунти недостатньо забезпечені валовими запасами і рухомими формами - фосфору - 1,0 мг, калію - 3,4 мг на 100 г абсолютно сухого грунту, а також гумусом - 1,97\%.

У бурих гірсько-лісових неглибоких кам'янистих пилувато-середньосуглинистих грунтах глибина верхнього гумусового горизонту темнувато-бурого кольору, коливається від 8 до 20 см, де по всьому профілю спостерігається щебінь та уламки твердих порід.

За даними наших аналізів, вони слабо насичені основами, ступінь насичення 46 \%, pН сольової витяжки - 4,0, сума увібраних основ становить - 6,8 м-екв, гідролітична кислотність - 8,05 м-екв на 100 г абсолютно сухого грунту. Також визначено в них підвищений вміст гумусу - 3,99\%, слабу забезпеченість рухомими формами фосфору - 1,0 та калію - 3,4 мг на 100 г абсолютно сухого грунту.

Встановлено, що грунти гірської зони відзначаються високим рівнем кислотності і вмістом органічних речовин на глибині до 35 см. Інші грунти залягають у сідловинах і на слабопологих схилах із високим вмістом органічних речовин, азоту й низьким - рухомих форм фосфору та калію. Для покращення родючості грунтів рекомендовано їх вапнування, також внесення фосфорних та калійних добрив. 
Відміни між грунтами, на яких ростає Centaurium erythraea, незначні, хоча він віддає перевагу нейтральним, з більшим вмістом гумусу. Виявлено значні розходження у відношенні рельєфу, а також інтенсивніше зростання природної популяції золототисячника малого на сонячніших та підвищених місцях.

\section{Висновки}

Centaurium erythraea у травосумішах найпоширеніший на середньокислих супіщаних, легких і середніх суглинних ґрунтах 3 pH - 4,7 - 5,1, та гідролітичною кислотністю 3,2 - 5,2 м-экв. на 100 г абсолютно сухого ґрунту.

Формування Centaurium erythraea, значною мірою, залежить від метеорологічних умов, який здатний витримувати заморозки і посухи влітку, порівняно з іншими видами рослин. Адаптація до значної контрастності природних умов Закарпаття, крутизни схилів, ґрунтів з різним рівнем родючості, надає значні переваги Centaurium erythraea.

\section{Література}

Григорюк, І., Фекета, І., Серга, О. 2008. Морфометричні показники природних популяцій золототисячника звичайного (Centaurium erythraea Rafh.) в умовах Закарпаття. Науковий вісник Начіонального аграрного університету, вип. 125, с. 42-46.

Деркач, В., Деркач, С. 2006. Золототисячник малий: можливості та проблеми культивування. Мат. міжнар. наук. конф. „Лікарські рослини: традиції та перспективи досліджень", с. 104-107.

Доспехов, Г. 1968. Методика полевого опыта. М.: Колос, 335 с.

Манівчук, Ю. 2003 Екологічно ефективні системи підвищення продуктивності лучних біогеоценозів Kapnam. Київ, 294 с.

Починок, Х. 1976. Методы биохимического анализа растений. 334 с.

Товстуха, Є. 1990. Фітотерапія. с. 68-69.

Фекета, І. 2011. Природні популяції золототисячника звичайного (Centaurium erythraea Rafh.) в умовах Закарпаття. Maт. міжнар. наук.- практ. конфер. „Екзо- та ендоекологічні аспекти здоров'я людини"Ужгород: „Говерла", с. 396-399. 